\title{
СМЕНА ПОЛИТИЧЕСКИХ ПОКОЛЕНИЙ В ГОРОДАХ СИБИРИ: ДИНАМИКА ОБРАЗОВ ВЛАСТНЫХ ОТНОШЕНИЙ В ОНЛАЙН- И ОФЛАЙН-СРЕДЕ
}

\author{
Ю.А. Пустовойт
}

\author{
(pustovoit1963@gmail.com) \\ Сибирский институт управления - филиал РАНХиГС \\ Новосибирск, Россия
}

Цитирование: Пустовойт Ю.А. Смена политических поколений в городах Сибири: динамика образов властных отношений в онлайн- и офлайн-среде // Власть и элиты. 2020. Т. 8, № 1. С. 148-169.

DOI: https://doi.org/10.31119/pe.2021.8.1.6

Аннотация. В иентре внимания статьи проблема политического выбора современной российской молодежи - миллениалов, родившихся после 1982 г. Согласно одним подходам, это поколение принципиально отличается от предыдущих, так как прошло юношескую социализацию в условиях относительного благополучия нулевых, что сказалось на снижении значимости политической составляющей в жизненных планах и появлении и росте других способов саморепрезентаиии (В. Радаев). Другие авторы (Ю. Левада) делают акиент на том, что вертикальные институты власти, конструирующие общество, остались неизменными, что способствует воспроизводству тех же архаичных черт, которые были присущи советскому человеку. Анализируются эмпирические исследования в Новосибирске и других сибирских городах, ход и итоги избирательных кампаний, тексты и образы политиков в новогодних обращениях и предмитинговых интернет-полемик («кейс 23 января»). Автор приходит к выводу, что

${ }^{1}$ Исследование выполнено при финансовой поддержке Сибирского института управления - филиала РАНХиГС в рамках научного проекта «Семья и дело. Образы семьи, дружбы и работы в жизненных стратегиях советских и постсоветских поколений сибирского мегаполиса». 
конструирование властных отношений в первую очередь строится на основе места в системе власти, специфики региона (города) и только потом на основе принадлежности к тому или иному поколению. Сейчас миллениаль, участвуюшие в политической жизни, занимаюшие место в публичных структурах власти, конструируют те же самыле подходы к использованию властных ресурсов, что и стариие возрастные группь.

Ключевые слова: поколения, бумерь, миллениаль, города, мобилизаизинная повестка, городской режим, идентичность, Сибирь.

Всплеск интереса к работам, выполненным в русле «теории поколений», обусловлен несколькими ведущими социально-политическими трендами. Происходит смена поколений во всех эшелонах власти в течении ближайших 10-20 лет, заметно увеличение юношества в протестных мероприятиях, становятся регулярными, повседневными «конфликты непонимания» между старшими и младшими возрастными группами. Судя по публикациям «о молодежи» и разговорам родителей, преподавателей и учителей, их взаимодействия пропитаны микроконфликтами различной степени тяжести. Расходятся языки общения, распространяется быстроизменяющийся и мультикультурный молодежный сленг, отличны способы получения информации и досуга (интернет vs телевизор). Конфликт отцов и детей, как утверждали классики психоанализа и как показано в художественной литературе, закономерен. Но не приобретает ли он новое, иное качественное содержание и интенсивность? Какое место в нем занимает власть и подчинение? Как и какой образ власти конструируется разными возрастными категориями? Как он реализуется в онлайн-дискуссиях и политическом поведении? Насколько динамика этого образа сопоставима с другими жизненными приоритетами, например семьей и профессиональной карьерой?

Одним из теоретических подходов, связывающих комплексы социально-политических проблем, вопросы возрастных изменений и условий социализации, выступает теория поколений. Наибольший интерес представляют работы, где описываются ценности, нормы, отношения и поведение поколения миллениалов (с 1982 г.р.) как наиболее «лакмусовой» когорты. На это поколение возлагали надежды возврата к «Великой Америке» У. Штраус и Н. Хоу, обосновывая этот процесс сменой архетипов «странников» на «героев» [Howe, Strauss 2000]. Они, согласно Р. Инглхардту, в большей степени отражают в западных обществах 
культурную эволюцию, рассматриваемую как переход от ценностей выживания к ценностям самореализации [Инглхардт 2020]. Они, согласно исследованиям Дж. Твенге, первыми с рождения пережили появление и расширение комплексов цифровых технологий, радости и соблазны сетевого общения, их воспитание строилось на безусловной высокой самооценке ребенка [Твенге 2019, 2020], именно они стали задавать стандарты повседневного потребления и стиля жизни, который в западном обществе характерен для наиболее обеспеченных слоев потребления [Соколов 2019]. В России это поколение находилось в фокусе внимания российских исследователей в контексте социального сдвига [Радаев 2019], модернизационных процессов [Левада 2016], изменения ценностей [Яницкий 2019; Юрчак 2016; Антипкин 2018].

Мнения о межнациональных сходствах и различиях в характеристиках поколений и возможности переноса основных положений американских авторов в российские реалии расходятся. «Все они изобретают свой словарь, спокойны, позитивны, экономичны, но одинаковы в разных странах в своем образе жизни. Они добры и виртуально открыты, но предпочитают общение в телефоне с рядом сидящим другом только потому, что не желают расходовать свой энергетический запас, чтобы передать свои чувства, контактировать и вести полноценный разговор на своем языке» [Лукина 2019: 164-183]. К такому выводу приходит Ю.В. Лукина на основе обзора работ, построенных на статистических данных Института здравоохранения США, подчеркивая не только сходство миллиниалов во всем мире, но и то, что треть американской молодежи страдает нарциссизмом.

Авторы доклада фонда «Петербургская политика» находят у российских миллениалов как универсальные черты, так и специфически российские характеристики. Вместе с некоторыми универсальными тенденциями - визуализацией, шерингом, отсутствием образа будущего, маркеров «свой - чужой», отказом от упорного труда, отожествлением счастья и успеха, жаждой признания, российские миллениалы имеют более низкие стартовые навыки по сравнению с американскими сверстниками, что, по мнению авторов доклада, превратит их скорее в жертв автоматизации, чем ее бенефициаров [Поколение Ү и поколение Z 2017]. Н.П. Попов в статье, посвященной сопоставлению характеристик и исследований российских и американских поколений, отмечает значимость «культурного кода» нации, сформированных на ее основе традиций и принципов организации общественной жизни. Для США - 
это либеральная демократия и расовое неравенство, для России - авторитаризм как элемент не только политической практики, но и массового сознания. По мнению автора, эти формальные и неформальные институты имеют большее значение, чем разрывы между поколениями [Попов 2018].

Из последних крупных исследовательских работ, построенных на широком теоретическом обзоре и опирающихся на комплекс эмпирических данных, выделим подход «поколенческого разлома», сформулированный В. Радаевым [Радаев 2019]. Здесь сделан акцент на социальном переломе 2000-х годов, когда в условиях относительного благополучия у российской молодежи появилось множество альтернатив выбора собственного образа жизни, что в общем и стало главной проблемой для самоопределения. Изобилие возможностей в условиях неопределенности, с одной стороны, создает психологическую проблему постоянной фрустрации вследствие страха ошибки, с другой - помещает область «политической активности» в одну из возможных и не всегда главных альтернатив жизненных проектов. В этом случае сложно найти некоторые общие темы со старшими возрастами, уверенными в верности избранного жизненного пути и значимости государственных решений при оценке собственного благополучия (но и неблагополучия). Ситуация приводит к межпоколенческому расколу, параллельному существованию, когда у представителей различных возрастных когорт нет общих тем для разговора. Новое поколение - действительно новое, и в их системе ценностей политика не играет особенной роли.

Напротив, в своих последних работах Ю. Левада утверждал, что в условиях закрытой вертикально-интегрированной институциональной структуры, где нет постепенной преемственности и обновления власти, возникает проблема «беспамятства» молодых, прагматиков на ключевых позициях, лишенных исторической памяти [Левада 2005: 58-59]. «Довольно распространенным лет 15 назад было представление о том, что с разрушением советской системы на общественную сцену выйдет новый человек, достойный гражданин свободной страны. Но такой же иллюзией была и надежда на то, что новое поколение, практически не знавшее советской жизни и советского воспитания, легко и просто изменит жизнь к лучшему... Это не новая молодежь, а всего лишь моложавая смена старой бюрократии, наследующая все черты и пороки своих предшественников. Они не обновляют обветшалые механизмы аппаратов управления, образования, науки и т.д., а встраиваются в них» 
[Левада 2016: 684]. Причина, по его мнению, заключается в том, что все проекты модернизации (тоталитарный проект лишь один из них) инициировались вертикальными, осевыми конструирующими общество институтами. «Надежда на спасительную руку государства не покидает людей, не умеющих найти силы в самих себе». Периферийное, закрытое общество, объединяемое вертикальными институтами власти, которые, по сути, не изменились, не имеет шансов на модернизацию [Левада 2016: 41].

В целом сторонники поколенческого подхода выделяют три критерия границ поколения: возрастные рамки, единые верования, ощущение причастности к своей возрастной когорте. Как правило, динамика и характеристики наиболее рельефно проявляются, когда речь идет о ценностях и поведенческих паттернах городского среднего класса, формирование характеристик поколения зависит от состояния институтов и выбора личных жизненных стратегий в момент юношеской социализации (18-25 лет), границы когорты обычно определяются 20 годами.

На наш взгляд, определенность в дискуссию о межпоколенных сходствах и различиях и изменении основных поведенческих характеристик возрастных когорт во времени могут внести исследования, направленные на процесс конструирования властных отношений. Базовым рабочим понятием для нас выступает «образ власти», т.е. реконструируемый комплекс высказываний о целях, границах и способах использования принуждения и насилия по отношению к «другим», в первую очередь политическим противникам. В. Ледяев из теоретического анализа властных феноменов в философии и науке выводит две традиции интерпретации властных отношений: «власть над...» как асимметричное отношение и игра с нулевой суммой, где рост власти одних автоматически означает потерю ее у других, и «власть для...», при которой власть может осуществляется к всеобщей выгоде [Ледяев 2012: 105-106]. На этой основе мы представляем «образ власти» как переменную с двумя полюсами. На одном - власть, конструируемая как полный, направленный на подавление интересов подвластных открытый контроль и принуждение, здесь действуют различные нормативные стандарты для властвующих и подвластных, и в предельном своем проявлении элитарные группы действуют по формуле «делай или умри». В нашей системе оценок эта власть обозначается как «1». На другом полюсе речь идет о влиянии. Управляющие и управляемые действуют по одной системе формальных и неформальных стандартов, на основе 
обоюдно признаваемых интересов и прав. Такой идеализированный концепт «власти для...», построенный на убеждении и авторитете, получит оценку «4» и может быть выражен аристотелевской формулой «общего блага». Промежуточные типы образов власти - «властьблокировка» («2»), основанная на молчаливом игнорировании интересов неэлитарных групп и пресечении какой-либо несанкционированной активности, и «власть-манипуляция» («3»), где конфликт интересов не осознается подвластными. Если в первом случае спонтанная политическая активность индивидов и групп не допускается в политическое поле (действует принцип «как бы чего ни вышло»), то во втором «индивид делает то, что хочет, но хочет он того, чего желают другие».

Принято считать, что модернизированное общество и его институты ориентированы на образы «власти для...», рассматривая ее (власть) как малозаметный производственный процесс сложного учета интересов и минимизации силового принуждения. Военная власть (которую мы рассматриваем как кризисный и экстремальный случай власти контроля) как источник социальной власти (экономического, политического, идеологического и силового средств реализации воли) вообще может исчезнуть в перспективе, считает М. Манн. «Все человеческие сообщества нуждаются в экономике, идеологии политике и судебном регулировании. Однако людям не нужна война, и если нет угрозы нападения, то нет нужды даже в обороне» [Манн 2018: 629].

В том случае если гипотеза В. Радаева имеет более весомые основания, то мы должны обнаружить в большем числе случаев у более молодых возрастных когорт тенденцию к конструированию власти в первую очередь на основе многоуровневого сочетания интересов или сложных манипуляций. Рост высказываний, ориентированных на расширение зоны силового принуждения, легитимацию насилия, приоритет борьбы над договоренностями, наоборот, подтвердит предположения Ю. Левады.

Результаты наших исследований в сибирских городах не претендуют на завершенность. Они скорее обозначают некоторые сходства и различия в видении политических и социальных проблем представителями различных поколений и задают направление следующему комплексу исследовательских работ. Нашу эмпирическую базу составляют анализ избирательных кампаний, интервью с представителями власти и лидерами протестных сообществ, сравнительный анализ онлайни офлайн-дискуссий на митингах начала 2021 г., материалы фокус-групп 
(г. Новосибирск) по изменению значений и приоритетности универсальных жизненных проблем.

Анализ результатов городских и областных избирательных кампаний в городах Томск и Новосибирск 2020 г. показывает, что новое политическое поколение миллениалов активно участвует в политике. Из них состоят штабы большинства оппозиционных партий и объединений. Число кандидатов молодого возраста, зарегистрированных на этих выборах по всем спискам, на четверть выше, чем близкого, но более старшего поколения реформ. При сопоставлении интервью представителей разных поколений отметим, что различия касаются скорее тональности сообщений. Чем старше интервьюируемый, тем вероятнее вне зависимости от политической позиции и статуса он будет жаловаться и обращаться к примерам из прошлого, чем моложе, тем больше точных аргументов и рациональных доводов. В большинстве случаев вне зависимости от возраста оценка личностей, ситуаций и действий строилась на основе моральных стандартов. Характерная черта молодых политиков - ориентация скорее на смыслы и ценности, чем на идеологические догматы или указания партийного руководства. Молодой человек в штабе КПРФ под огромном портретом Сталина будет рассматривать комплекс современных проблем на современном языке менеджмента и юридических норм. Представители старших возрастных групп больше внимания и времени уделяют опасностям и проблемам, связанным с властью чиновников-силовиков, алчностью и неконтролируемостью бизнесменов, ужасам национализма и намного чаще используют «образ врага» с соответствующим набором ярлыков [Пустовойт 2020].

Для того чтобы выявить различия в «образах власти», мы собрали и сопоставили новогодние обращения и выложенные в интернет фото политиков руководителей и лидеров оппозиции в столицах сибирских регионов - Новосибирске, Томске, Барнауле, Кемерово, Новокузнецке, Абакане. Эти города рассматриваются нами как «естественные лаборатории», с одной стороны, отражающие политические процессы на федеральном уровне, с другой - отличающиеся локальной спецификой, связанной со структурой экономики, уровнем комфорта и потребления, перспективами для молодежи, городскими режимами и протестной активностью. Ситуацию в них мы подробно изучали в течение последних шести лет. В качестве ключевых политических фигур были выбраны губернатор области, глава города, председатель местного законо- 
дательного собрания и лидеры местной системной и несистемной оппозиции. Таким образом, мы построчно просмотрели материалы обращений (более 30 местных политиков), их страницы в социальных сетях и фото (обычно 15-20 фото на человека). Новогоднее обращение выступает значимым ритуалом, символизирующим связь политического деятеля с населением, его видение настоящего, прошлого и будущего, что, безусловно, находит свое отражение и в тиражируемых текстах, и в конструируемом визуальном образе.

Были взяты за основу принципы метода обоснованной теории [Страусс, Корбин 2001: 52-119]. Процедура качественного анализа обычно состоит из двух этапов: сведение текста к сегменту (коду) на основе выделения основной смысловой единицы иногда с добавлением цитаты-иллюстрации кода и интерпретация кода исследователем и далее поиск смысла связей между различными смысловыми единицами. Значимо обозначение адресной аудитории, ее наименование (земляки, друзья, жители...), интерпретация смысла кода (о чем, собственно говоря, идет речь, что находится в фокусе внимания, с какими ценностями и нормами соотносится выступление, какой эмоциональный и рациональный месседж содержится и т.д.) и вывод, призыв к действию. Работа с визуальными образами и их интерпретацией велась на основе принципов, сформулированных П. Штомкой [Штомпка 2006], где главный исследовательский вопрос звучал в духе Р. Барта - «Какой образ власти стоит за изображением?»

Здесь мы рассмотрим только наиболее яркие случаи, приведем примеры обращений, политиков, находящихся на разных должностях и в разных правовых статусах и обстоятельствах. Главным для нас является нахождение сходств и различий в конструировании власти представителями советских и послесоветских поколений. Вначале мы рассмотрим четыре случая высказываний «старших» политиков, занимающих серьезные должности в структуре исполнительной власти, затем четыре случая политиков-миллениалов, преимущественно депутатской оппозиции, и одного губернатора.

В совместном с председателем Алтайского краевого Законодательного собрания поздравлении с Новым годом и Рождеством губернатор В.П. Томенко (1971 г.р. инженер-экономист) обратился к «дорогим жителям Алтайского края», а затем перешел к адресатам более узкого сообщества — «близкие люди - родители, дети и друзья» и далее начал подводить итоги «не самого простого» года с акцентом на героизме 
врачей и медсестер и сохранении социальных гарантий, сборе достойного урожая и ремонте дорог, школ, больниц и поликлиник. Закончил напоминанием о юбилее - 75-летии Великой Победы и пожеланием загадать желания, сбывания мечтаний и нахождения рядом родных и близких людей [Губернатор Алтайского края 2020]. «Инстаграм» Виктора Томенко (225 публикаций, 107 подписчиков) включает снимки и видео православно-военной и спортивной тематики, разбавляемые иногда фото с детьми и производственными сюжетами. Фото имиджевые, в традиционном официальном стиле, вызывающие знакомые коннотации на тему «Начальство руководит, объясняет и спрашивает...» ${ }^{1}$.

Арестованный мэр Томска И.Г. Кляйн, 1979 г.р., специалист по автоматизированным системам управления, генеральный директор ОАО «Томское пиво, передавал поздравление через адвокатов и Telegramканал [Томский мэр перебрал 2020]. На официальном портале администрации по-прежнему висит его прошлогоднее видеообращение, где под новогодний праздничный городской видеоряд (новогодний Томск, жители и государственная символика) Иван Кляйн, обращаясь к томичам, говорит о национальных проектах, благодаря которым мы «ремонтируем дороги, строим жилье и т.д.» [Новогоднее поздравление мэра Томска 2019].

Переданное в декабре 2020 г. через защитников обращение состоит из обычных трех частей: обращение с поздравлением, напоминание о тяжелых испытаниях и надежды на возвращение к нормальной жизни, благодарность за поддержку и теплые слова и констатация значения веры, надежды и любви к детям, родителям, близким, к своему дому и городу («Только это имеет значение по-настоящему»). Заканчивается послание пожеланием здоровья, успехов и праздничного настроения [Арестованный мэр 2020]. Над обращением 30 декабря в группе «Дело Кляйна ${ }^{2}$ расположено символическое темное фото томского катка «Под звездным небом», сочетающего светящийся, созданный искусственными гирляндами верх и темный низ, с несколькими катающимися горожанами за серыми (грязными) барьерами. Снимок, скорее всего,

${ }^{1}$ Персональная страница в «Инстограме». URL: https://www.instagram.com/ gubernator_tomenko/?hl=ru (дата обращения: 01.12.2021).

${ }^{2}$ Группа в телеграмм-канале «Дело Кляйна». URL: https://t.me/KleinDefense/62 (дата обращения: 01.12.2021). 
не попадет в серию «праздничное настроение». Остальные фото - это образы политика (около 30 первых фото на запрос), традиционные имиджевые портреты в официальной (пиджак, галстук, значок) одежде. Здесь практически нет эмоций (выражение лица на двух третях снимков больше «серьезное») и меньше символов власти (одно фото с губернатором, одно с флагом, одно в кресле и одно с выпускниками школ с интригующей и диссонансной относительно выражения лица мэра подписью «Иван Кляйн - веселый мэр Томска»).

Мэр Новокузнецка С.Н. Кузнецов (1969 г.р., факультет иностранных языков) поздравил горожан в «Инстаграме» ${ }^{1}$. Традиционное по форме видеообращение (за год до этого поздравление было из проруби) больше обычного по объему (4 минуты), начинается с обращения «Уважаемые новокузнечане, дорогие друзья» и далее говорится о Ковиде, ограничениях, раздаются поклоны медикам, педагогам, волонтерам, идет переход к смене приоритетов и тому, что «творить добро стало нормой», спасибо автоволонтерам, далее отмечается 75-летие Победы и присвоение городу звания «Город трудовой доблести», поклон ветеранам и труженикам тыла и почитание традиций. Заканчивается набором пожеланий счастья, тепла и удачи. Имиджевые фото политика мало отличаются от обычных фотографий политиков, хотя в гуглкартинках есть пара снимков с обнаженным торсом. В социальных сетях, которые ведутся как дневник, фото самых разных сюжетов. Здесь градоначальник обычно в более неформальной одежде. Иногда в спортивной, хоккейной форме, композиции подчеркивают динамику, движение. Примерно треть сообщений на ленте - видеосюжеты на разные темы: работа транспорта, очистка снега, молодежь, награждения, распоряжения и т.д.

А.В. Лемин (1975 г.р., кандидат экономических наук), глава города Абакана, начинает новогоднее поздравление «Дорогие абаканцы» и обращается к детским воспоминаниям, «когда мохнатые лапы ели были душистые и мягкие». Далее отмечает, что год был «совершенно другим» и многое изменилось, но рядом с каждым из нас были близкие люди, теплая надежная душа», «несмотря ни на что, мы будем творить», заканчивается послание пожеланием: «Желаю каждому из вас чуда, и не только новогоднего <... >, достижений и открытий, здоровья

${ }^{1}$ Персональная страница в «Инстограм». URL: https://www.instagram.com/ tv/CJdtNUBIQIv/?hl=ru (дата обращения: 01.12.2021). 
и любви». Видеотекст, скорее, ориентирован на эмоциональное объединение, усиленное доверительной тональностью, использованием суггестивных NLP-техник и обращением к общим детским воспоминаниям [Глава Абакана поздравил с Новым годом 2020]. Есть страница «ВКонтакте» ${ }^{1}$ (3744 друга, 326 фото) и несколько снимков в «Инстаграме» (Команда Булакина). Лента построена по принципу дневника, много неформальных фото, а также фото из горных походов и спортивных состязаний. На снимках из гугл-картинок часть имиджевых фото сделаны в свободном стиле, с расстегнутым воротом, эмоционально-выразительны, снимки в рабочем кабинете без атрибутики власти.

Лидер томской оппозиции (К.В. Фадеева, 1998 г.р., международный факультет управления, с 2020 г. депутат городской Думы) зарегистрирована во всех социальных сетях, сейчас профили с ограниченным доступом ${ }^{2}$. Краткое обращение размещено на странице «ВКонтакте», в группе «Команда Навального/Томск». Год характеризуется как «год эпидемии, изоляции, потрясений и побед» ${ }^{3}$. Далее подчеркивается, что главное - победа сотрудников штаба на выборах в Думу и благодарность за поддержку. Поздравление с Новым годом и напоминание о том, что штаб на каникулах. В отличие от предыдущих политиков, здесь фото сделаны в самых разных жанрах и ракурсах. В лентах социальных сетей (например, в «ВК» на момент исследования было отмечено 1593 подписчика, 2445 друзей и 321 фото) идут политические репортажи, селфи с друзьями, зарисовки из путешествий, официальные документы, агитационные материалы. Хотя снимки иногда повторяются, в целом фотографии в каждой из социальных сетей скорее связаны со спецификой ресурса. «Фейсбук» - больше индивидуальные и групповые фото о политической борьбе (митинги, обращения, пикеты),

${ }^{1}$ Персональная страница в «BK». URL: https://vk.com/id194440347 (дата обращения: 01.12.2021).

${ }^{2}$ С 9 июня 2021 г. Мосгорсуд признал экстремистскими организациями «Фонд борьбы с коррупцией» (ФБК, признан иноагентом) Алексея Навального, а также «Фонд защиты прав граждан» (ФЗПГ; юрлицо ФБК, признан иноагентом) и штабы оппозиционера. Подробнее см.: РБК. URL: https://www.rbc. ru/politics/09/06/2021/608670e09a7947709c4de06c (дата обращения: 13.12.2021).

${ }^{3}$ Этот материал заблокирован на территории РФ на основании требования Генеральной прокуратуры Российской Федерации от 15.06.2021 № 27-31-2021/ Ид6832-21 (дата обращения: 13.12.2021). 
«Инстаграм» - художественные снимки, личные впечатления, эстетика места и времени. Первые 17 снимков по запросу в основном индивидуальные в свободной офисной одежде (красный пиджак), несколько снимков с митингов и агитационных плакатов, молодость, эмоциональность, движение - так можно обозначить основной комплекс ассоциаций.

Новогодние поздравления лидера новосибирской оппозиции С.А. Бойко (1983 г.р., закончил информационные технологии НГУ) размещены на разных ресурсах, отличаются друг от друга содержанием и тональностью. В целом в фокусе внимания сложности становления и проблемы организации «Коалиции 2020», надежды на преодоление и политические планы на год: выборы в Государственную думу и попытка отставки «нерадивого мэра»‥ Фото в «Инстаграме» (446 публикаций, 19,3 тыс. подписчиков) разбиты по темам «Горсовет», «Маска» и т.д. Лента в «Фейсбуке»- неформальные встречи и политические материалы, в группе «ВК» - близкая по теме лента новостей. Снимки политика, как правило, портретные, но в неформальной одежде, часто на фоне города, зданий и агитационных материалов. Статусных признаков нет, подчеркиваются различия с действующими официальными политиками: легкая небритость, отсутствие галстука, новогодние снимки с бокалом, вместо галстука - красная бабочка. Большинство снимков можно интерпретировать в категориях «свободы, равенства, братства», имиджа - «я такой же, как вы», легкости и непринужденности.

Новогоднее обращение главы Республики Хакассия В.О. Коновалова (1987 г.р., юрист) на фоне елки и в окружении символов государства и республики начинается с обращения «Уважаемые друзья». Дальше говорится об испытании на прочность, изменении и сплочении [Глава Хакассии Валентин Коновалов...2020]. Второй абзац посвящен достижениям в строительстве новых школ, садов и спортивных сооружений, подчеркивается, что это результат труда всех земляков, которые «любят и ценят свою малую Родину». Заканчивается пожеланиями мира, благополучия любви, здоровья и исполнения желаний. Глава республики активен в социальных сетях «ВКонтакте» (23 тысячи подписчиков, 9961 друга, 4866 фото), «Инстаграм» (2048 публикаций, 74,2 тыс. подписчиков), ведет свой блог и регулярно общается на ютуб-канале

${ }^{1}$ Персональная страница в «Инстаграме». URL: https://www.instagram. com/p/CJd4x6PCzWT/ (дата обращения: 01.12.2021). 
$(8,43 \text { тыс. подписчиков })^{1}$. Хотя большая часть фото - официальный дневник (заседания, повестки совещания), часть снимков - с неформальных (баня) и семейных мероприятий. Ленты в социальных сетях практически дублируют друг друга. Гугл-картинки показывают имиджевые официальные фото, часть с государственной символикой, часть с символикой КПРФ. Примерно половина официальных снимков эмоционально выразительные, причем диапазон эмоций самый разнообразный.

Близкий по возрасту и политической активности в 2020 г. позиционирующий себя как лидер протестного объединения Денис Щедрин (1981 г.р., инженер), руководитель движения «Сила Кузбасса» («ВКонтакте» 2028 подписчиков, 8881 друга, 95 фото) на Новой год опубликовал два поздравления от себя и движения. Тексты идут без обращения и представляют собой комплекс пожеланий, где соседствуют новые надежды, успехи и победы, подчеркивается необходимость наличия энергии и смекалки, ясные и конкретные планы социально-экономического развития и реальные возможности их воплощения в жизнь. Из приоритетов назван достаток в доме, мир и любовь в семье. Снимки в ленте - несколько портретных фото и открытки. Часть фото любительские, как правило, на снимках политик в костюме и в галстуке, тексты в основном в «боевой» тональности («я настроен на борьбу...», «держитесь, чиновники...») ${ }^{2}$.

Все новогодние обращения можно разделить на две группы. В первом случае (характерном для представителей власти) новогодняя повестка как уверенность в будущем и оптимизм достигается за счет повторения фраз о победах в прошлом и перечисления некоторых желательных эмоций и коллективных трудовых достижений. В новогодних поздравлениях представители действующей власти обращаются к населению «как к равным», подчеркивая его «ценность» и значимость близкому социальному и повседневному кругу взаимодействия (семья, друзья) и далее начинают конструировать или обозначать «желаемые для себя» эмоциональные состояния. Хотя аудитория послания, возможно, не испытывает требуемого от него «социального оптимизма»,

${ }^{1}$ Персональный блог. URL: https://www.youtube.com/c/ValentinKonovalov1917 (дата обращения: 01.11.2021).

${ }^{2}$ Персональная страница в «BK». URL: https://vk.com/denis9832509000 (дата обращения: 01.11.2021). 
не особенно верна «прошлым традициям», «трудовым успехам» и не придает значимости реализации национальных проектов. При этом обычно визуальный ряд не соответствует вербальному. Предлагаемые фото образов политиков - это истории предельно индивидуального (даже не семейного) успеха в достижении власти и высокого уровня благосостояния. На подавляющем большинстве фотографий - герой в галстуке в статусной одежде, иногда в окружении символов власти. В предложенной нами системе оценок конструируемый образ власти получит 1-2, что можно подтвердить «силовой» символикой, насыщенной военными элементами и настраивающими на бескомпромиссную войну.

Во втором случае (характерном для более молодых и оппозиционных политиков), тема обращений сосредоточена на настоящем. Если представители власти говорят скорее о том, что должны переживать «другие», то оппозиция, обращаясь к своим сторонникам, говорит о себе, своих планах, конфликтах, переживаниях и перспективах. Как правило, здесь в фокусе политического внимания разрыв между желаемым и происходящим. Концентрация на настоящем в этой повестке снимает необходимость точной артикуляции будущего, проговаривание испытываемых эмоций, локализация материальных проблем служит стимулом для объединения и участия в коллективных мероприятиях. Обычно визуальный ряд соответствует вербальному, декларированные идеи и ценности отражены в фотосюжетах, в которых подчеркивается индивидуализм, свобода, спонтанность, диалог. В нашей системе оценок конструирования образа власти - это больше 3-4.

Для того чтобы понять, какие образы власти преобладают в той или иной возрастной аудитории и в разных городах, мы обратились к случаю «23 января» и призыву А. Навального выйти на митинг. С помощью поисковой машины IQBuzz, созданной для отслеживания репутации в интернете, мы получили и проанализировали определенный массив сообщений. Система провела мониторинг социальных медиа по заданному поисковому запросу - СвободуґНавальному АлексейґНавальный

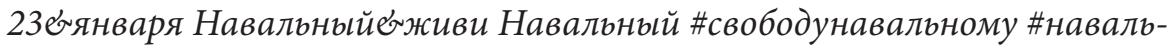
ныйживи \#митинг23января \#протест. Мониторинг осуществлялся за период с 20 по 26 января 2021 г. (три дня до митинга, три после), на русском языке, по России и регионам, в которых расположены интересующие нас города с известными мобилизационными повестками (оценка эффективности действий оппозиции) Новосибирск, Томск, 
Абакан, Барнаул, Кемерово, Новокузнецк. Алгоритм автоматически определяет тональность собранных материалов, но поставленные ей оценки требуют корректировки. Отнесение сообщения к негативному или позитивному не означает отрицательной или положительной оценки мероприятия, личности, политика и т.д., так как система просто определяет общий эмоциональный настрой автора, но обычно не указывает объект этого настроя. Выделили пики дискуссий, т.е. день и время, когда проходило основное обсуждение, и определяли в эти дни основные социально-демографические характеристики их участников. Для нас здесь важен возраст, в системе он не совпадает с границами поколений, но дает представление о том, как реагируют различные возрастные когорты на сообщения.

По разным оценкам, 23 января 2021 г. в 198 городах России и 95 городах за рубежом в митингах приняло участие от 110 тыс. до 250 тыс. человек. В ходе протестов было 4 тыс. задержанных, из которых около $300-$ несовершеннолетние ${ }^{1}$. Для нашего анализа важно знать, что часть информации (например, в сети «ВКонтакте» - 50 \%) была заблокирована и удалена по требованию Генеральной прокуратуры, и система не учитывала ряд популярных ресурсов (например, «Фейсбук», «Твиттер» и т.д.). Поисковая система обнаружила за этот период 14641 сообщение (73 \% от всего массива), из них 1353 оценила как негативные, 274 как позитивные, 106 как смешенные, тональность остальных автоматически не обработана (помечаются как нейтральные). Негативные сообщения преобладают в массиве и среди более молодой аудитории.

${ }^{1}$ Акции 23 января. Главное Мощное выступление регионов, три тысячи задержанных (это рекорд). И уже более 10 уголовных дел // Медуза. 24.01.2021. URL: https:/meduza.io/feature/2021/01/24/aktsii-23-yanvarya-glavnoe (дата обращения: 01.11.2021). (С 23 апреля 2021 г. издание «Медуза» должно ставить дисклеймер: данное сообщение (материал) создано и (или) распространено иностранным средством массовой информации, выполняющим функции иностранного агента, и (или) российским юридическим лицом, выполняющим функции иностранного агента.); Новая акция в поддержку Навального. Главное // РБК. 31.01. 2021. URL: https://www.rbc.ru/politics/31/01/2021/6013f 2a99a79474815347780?fbclid=IwAR0Elq40krN0GWYmZWDcqJxraDrfPn7LsGKIfxZ6_FoWW01ulpVzGqk_-w (дата обращения: 01.11.2021); Кто они эти протестующие. Пост Александры Архиповой. 02.02.2021. URL: https://www. facebook.com/photo?fbid=4562372340457020\&set=a.101960386498260 (дата обращения: 01.11.2021). 
По числу комментариев, лайков и репостов (из 30 отобранных текстов все «ВКонтакте», 18 материалов закреплены за группами, 12 - индивидуальные, 6 не имеют к обсуждаемой теме никакого отношения).

Из самых популярных 30 сообщений, отобранных системой, половина закреплена за группами, половина за авторами, критически относящимся к митинговой активности. Их тональность вызывает мало сомнений в характере дискуссии и «образе власти» их носителей. Например: После первой волны митингов полноценную жертву тирании найти не получилось (тему питерской тетушки, которую полицейский ударил ногой в живот, система отработала). В последующих митингах, чтобы в «движняк» включить не только политически активных граждан, но и, главное, обывателей, такая жертва неизбежно должна появиться. И после этого начнется уже совсем другая история (депутат от КПРФ, 1984 г.р., 21 комментарий, 114 лайков и 34 перепоста). Пару слов в зашиту молодежи вышедшей на несанкиионированные акции протеста 23 января. Они вышли туда не потому что их за собой позвал Навальный, они вышли туда, потому что чувствуют острую несправедливость в обществе, потому что их терпение лопнуло раньше, чем терпение у их родителей. 23 января не случилось бы, если бы более стариее поколение активнее принимало участие в политической жизни» (32 года, 25 комментариев, 45 лайков, 12 репостов) ${ }^{2}$ (орфография и лексика сохранены).

Общая тенденция по числу найденных системой документов (из нее выпадает Томск) - чем больше сообщений, тем больше участников мероприятий. В каждом городе и регионе в фокусе внимания находилась своя группа проблем. В Новосибирске и Томске доминировала агрессивная и уничижительная критика, направленная против сторонников митинга, немного разбавленная депутатскими постами с пафосной аргументацией. В Кемеровской области 23 января прошло под условным лозунгом «защитим детей», и все усилия администрации и ее сторонников в цифровой среде были направлены на предотвращение гипотетического детского бунта. В Абакане старшая возрастная категория «устыжала» и осуждала лидера оппозиции как нарушителя спокойствия,

${ }^{1}$ Персональная страница в «BK». URL https://m.vk.com/wall866562_4207 (дата обращения: 01.11.2021).

${ }^{2}$ Персональная страница в «Однокласниках». URL https://ok.ru/artcibashev/ statuses (дата обращения: 01.11.2021). 
агента воображаемого Запада и т.д. В Барнауле критика протестующих велась в основном из классовых, марксистских позиций.

Во всех случаях в фокусе внимания была личность Навального, а не ситуация и ее правовая оценка. Обычно тексты строились по общему алгоритму: оценка личности (герой или подлец) - гипотетическая причина (возмущение несправедливостью и обличение сильных - отрабатывание денег хозяев) - сторонники и их характеристики (честные бесстрашные граждане - молодые безмозглые сумасшедшие), оценка результата (неадекватные репрессии - наведение законного порядка).

\section{ЗАКЛЮЧЕНИЕ}

По имеющимся у нас материалам можно утверждать, что конструирование образа власти строится на основе места в системе власти, специфики региона (города) и только потом на основе принадлежности к тому или иному поколению.

Образ власти зависит в первую очередь от позиции в системе властных отношений. Занятие официальной «системной» политической позиции означает следование эмоциональным, рациональным и поведенческим паттернам в логике власти-контроля, окружение себя символами, подчеркивающими государственную мощь, следование воинским традициям и рассмотрение повседневной жизни в категориях долга, подвига и успеха.

Здесь есть определенная региональная (городская) специфика, связанная с особенностями местной социально-экономической жизни и имеющимися объемами культурного и социального капитала. В наиболее модернизированных и благополучных городах правящие группы ориентированы на индивидуальный отбор и инкорпорацию активных миллениалов в политическую систему через механизмы различных школ и конкурсов и далее включения наиболее перспективных в циклы электоральной и партийной конкуренции. В регионах со сложившейся авторитарной моделью управления (Кемеровская область) официальная власть активно зачищает политическое поле от всех возможных оппонентов, выдавливая их в другие регионы, и прекращает любую дискуссию, переводя ее в административное поле обеспечения безопасности. В городах с более сложной экономической ситуацией (Барнаул) при росте инициативы и активности оппозиции происходит обострение политической борьбы и в социальных сетях, и на площадях. Здесь оппо- 
зиция («системная») может добиться определенного успеха (Абакан), но в силу сложившихся образов власти («власти над...») и ограниченности прежде всего экономических ресурсов ей вряд ли удастся создать устойчивые локальные коалиции власти.

Что касается поколенческого фактора, то пока он проявляется в стилистических отличиях, способах коммуникации и саморепрезентации. Чем моложе возраст, тем более значима политика в онлайн-измерении. Взаимодействие в политических институтах, организациях и уличной активности для молодых политиков сразу находят свое отражение в цифровой среде. Более старшее поколение проявляет сетевую активность, за редким исключением, только в наиболее модернизированных городах. Наиболее яркие различия мы увидели преимущественно в эмоциональной сфере. Миллениалы, как правило, ярко демонстрируют свои эмоции на публике, артикулируют свои переживания по любому поводу, не проводя особенных различий между личной и общественной жизнью, тяготея к сильному выражению чувств, гневу по отношению к политическим оппонентам и эмоциональному принятию союзников и последователей.

Основной символический конфликт проходит между «властными» и «провластными» сообществами, имеющими конкурентные коллективные и индивидуальные преимущества в рамках официальной политики, и теми, кто их не имеет («несистемной оппозицией»). «Разлом» как отказ от коммуникации и полное неприятие оппонента проходит скорее внутри каждого поколения, между ровесниками, часть которых включена в официальную политическую систему, а часть действует в политическом поле самостоятельно.

В целом гипотеза Ю. Левады выглядит более состоятельной. Миллениалы, участвующие в политической жизни, занимающие место в публичных структурах власти и «системной оппозиции», конструируют образ власти на основе контроля, «власти над...». В этом контексте, если рассматривать города как «естественные лаборатории», перспективы либерализации и демократизации российского общества переносятся уже в «очень отдаленное будущее».

\section{Литература}

Анипкин М. А. Поколение «лишних людей»: антропологический портрет последнего советского поколения // Неприкосновенный запас. Дебаты о политике и культуре. 2018. №. 1. С. 290-308. 
Инглхарт Р. Культурная эволюция. Как изменяются человеческие мотивации и как это меняет мир. M.: Litres, 2020. 400 с.

Левада Ю. Время перемен: Предмет и позиция исследователя. М.: Новое литературное обозрение, 2016. 872 с.

Левада Ю., Шанин Т. Отцы и дети: поколенческий анализ современной России. М.: НЛО, 2005. 328 с.

Ледяев В. Г. Социология власти: теория и опыт эмпирического исследования власти в городских сообществах. М.: ИД НИУ ВШЭ, 2012. 472 с.

Лукина Ю.В. Миллениалы, их характер, особый словарь и влияние на бизнес по всему миру // Язык. Культура. Общество. Актуальные вопросы, методы исследования и проблемы преподавания: сб. науч. ст. / отв. ред. И.Е. Коптелова. М.: Дипломатическая академия; Квант Медиа, 2019. С. 164-183.

Манн М. Источники социальной власти. Т. 4: Глобализации 1945-2011 годы. М.: Издат. дом «Дело» РАНХиГС, 2018. 672 с.

Радаев В. Миллениалы. Как меняется российское общество. М.: Издат. дом Высшей школы экономики, 2019. 230 с.

Соколов М. М. Поколения вместо классов? Возраст и потребительская революция в России // Социология власти. 2019. Т. 31, № 1. С. 71-91.

Страусс А., Корбин Дж. Основы качественного исследования: обоснованная теория, процедуры и техники. М.: Эдиториал УРСС, 2001. 256 с.

Поколение $\mathrm{Y}$ и поколение $\mathrm{Z}$ в поиске собственных мест под Солнцем // Фонд «Петербургская политика». 19.04.2017. URL: https://fpp.spb.ru/fpppokolenie-xyz (дата обращения: 10.08.2018).

Попов Н.П. Российские и американские поколения XX века: откуда пришли миллениалы? // Мониторинг общественного мнения: экономические и социальные перемены. 2018. № 4. С. 309-323. https://doi.org/10.14515/monitoring.2018.4.15.

Пустовойт Ю. А. Протест как крик, работа и вера: формирование протестной идентичности (по результатам исследований в сибирских городах) // Вестник Томского государственного университета. Философия. Социология. Политология. 2020. № 57. С. 277-284. doi: 10.17223/1998863X/57/26.

Твенге Д. Поколение І. М.: Рипол Классик, 2019. 464 с.

Твенге Д. Поколение селфи. Кто такие миллениалы и как найти с ними общий язык. M.: Litres, 2020. 336 c

Штомпка П. Визуальная социология: фотография как метод исследования. М.: Логос-М, 2007. 231 c.

Юрчак А. Это было навсегда, пока не кончилось. Последнее советское поколение. М.: НЛО, 2016. 664 с.

Яницкий М.С. и др. Система ценностных ориентаций «поколения Z»: социальные, культурные и демографические детерминанты // Сибирский психологический журнал. 2019. № 72. С.46-67.

Howe N., Strauss W. Millennials rising: The next great generation. New York: Vintage, 2000. $432 \mathrm{p}$. 


\section{Источники}

Арестованный мэр Томска поздравил горожан с Новым годом // Коммерсант. 31.12.2020. URL: https://www.kommersant.ru/doc/4638155 (дата обращения: 01.12.2021).

Глава Абакана поздравил с Новым годом // Пульс Хакассии. 31.12.2020 URL: https://pulse19.ru/80829-glava-abakana-pozdravil-s-novym-godom/ (дата обращения: 01.12.2021).

Глава Хакасии Валентин Коновалов поздравил жителей республики с наступающим Новым годом // Правда 19. 30.12.2020. URL: http://pravda19. ru/2020/12/30/ (дата обращения 01.12.2021).

Губернатор Алтайского края Виктор Томенко поздравляет // Вести-Алтай. 31.12.2021. URL: https://www.youtube.com/watch?v=SgYPOi8PHWA\&ab_channelВести-Алтай (дата обращения: 01.12.2021).

Новогоднее поздравление мэра Томска // Администрация города Томска официальный сайт. URL http://admin.tomsk.ru/pgs/cax (дата обращения: 01.12.2021).

Томский мэр перебрал с пивом. Ивана Кляйна взяли в прямом эфире // Коммерсант. 13.11.2020. URL: https://www.kommersant.ru/doc/4573132 (дата обращения: 01.12.2021).

\section{THE CHANGE OF POLITICAL GENERATIONS IN SIBERIAN CITIES: THE DYNAMICS OF POWER RELATIONS IN ONLINE AND OFFLINE ENVIRONMENTS}

\section{Y.A. Pustovoit}

(pustovoit1963@gmail.com) Siberian Institute of Management - the branch of the Russian Presidential Academy of National Economy and Public Administration Novosibirsk, Russia

Citation: Pustovoyt Yu. Smena politicheskikh pokoleniy v gorodakh Sibiri: dinamika obrazov vlastnykh otnosheniy v onlayn i oflayn srede [The change of political generations in Siberian cities: the dynamics of power relations in online and offline environments]. Vlast' i elity [Power and Elites], 2021, 8 (1): 148-169. (in Russian)

DOI: https://doi.org/10.31119/pe.2021.8.1.6

Abstract. The author's vision of the process of change of political generations is considered. The problem of political choice of modern Russian youth - millenials 
born after 1982 is in the focus of attention. According to some approaches this generation is fundamentally different from the previous ones, because it went through youth socialization in the conditions of relative well-being of the zero years, which led to the decline of importance of the political component in life plans and the appearance and growth of other ways of self-representation (V. Radaev). Other authors (Y. Levada) emphasize that the vertical institutions of power that construct society remained unchanged, which contributes to the reproduction of the same archaic features that were inherent in the Soviet man. On the basis of empirical research in Novosibirsk and other Siberian cities, the course and results of election campaigns, the analysis of texts and images of politicians in New Year's addresses and internet polemics ("the case of January 23 ") the author comes to the conclusion that the construction of power relations is primarily based on the place in the power system, the specificity of the region (city) and only then on the membership in this or that generation. Millennials, who participate in political life and occupy a place in the public structures of power, construct the same approaches to the use of power resources as older age groups.

Key words: generations, "boomers", "millennials", cities, mobilization agenda, urban regime, identity, Siberia.

\section{References}

Anipkin M. A. Pokolenie" lishnikh lyudey": antropologicheskiy portret poslednego sovetskogo pokoleniya [Generation of "superfluous people": an anthropological portrait of the last Soviet generation]. Neprikosnovennyy zapas. Debaty o politike $i$ kul'ture. [Debates on politics and culture], 2018, 1, pp 290-308. (In Russian)

Howe N., Strauss W. Millennials rising: The next great generation. New York: Vintage, 2000. $432 \mathrm{p}$.

Inglkhart R. [Inglehart R.] Kul'turnaya evolyutsiya. Kak izmenyayutsya chelovecheskie motivatsii $i$ kak eto menyaet mir [Cultural evolution. How human motivations change and how it changes the world]. Moscow: Litres, 2020. 400 p. (In Russian)

Ledyaev V. Sotsiologiya vlasti: teoriya i opyt empiricheskogo issledovaniya vlasti $v$ gorodskikh soobshchestvakh [Sociology of power: theory and experience of empirical research of power in urban communities]. Moscow: HSE, 2012. 472 p. (In Russian)

Levada Yu. Vremya peremen: Predmet i pozitsiya issledovatelya [Time for change: The subject and the researcher's position]. Moscow: Novoe Literaturnoe Obozrenie [New Literary Review], 2016. 872 p. (In Russian)

Levada Yu., Shanin T. Ottsy $i$ deti: Pokolencheskiy analiz sovremennoy Rossii [Fathers and Children: A Generational Analysis of Contemporary Russia]. Moscow: Novoe Literaturnoe Obozrenie [New Literary Review], 2005. 328 p (In Russian)

Lukina Yu. V. Millenialy, ikh kharakter, osobyy slovar' i vliyanie na biznes po vsemu miru [Millennials, their character, special vocabulary and the impact on business around the world]. In: Yazyk. Kul'tura. Obshchestvo. Aktual'nyye voprosy, metody issledovaniya i problemy prepodavaniya: sb. nauch. st. [Language. Culture. Society. Topical issues, research 
methods and teaching problems: collection of scientific articles]. Ed. by I.Ye. Koptelova. Moscow: Diplomaticheskaya akademiya: Kvant Media, 2019, pp. 164-183. (In Russian)

Mann M. Istochniki sotsial'noy vlasti. Tom 4: Globalizatsii 1945-2011 gody [Sources of social power. Vol. 4: Globalizations 1945-2011]. Moscow: "Delo" Publishing House RANEPA. 2018. 672 p. (In Russian)

Pokolenie $\mathrm{Y}$ i pokolenie $\mathrm{Z} v$ poiske sobstvennykh mest pod solntsem [Generation $\mathrm{Y}$ and Generation $\mathrm{Z}$ in search of their own places under the Sun]. Fond «Peterburgskaya politika». [St. Petersburg Policy Foundation], 2017. URL: https://fpp.spb.ru/ fpp-pokolenie-xyz (access: 10.08.2018). (In Russian)

Popov N.P. Rossiyskie i amerikanskie pokoleniya XX veka: otkuda prishli millenialy? [Russian and American generations of the 20th century: where did the Millennials come from?]. Monitoring obshchestvennogo mneniya: ekonomicheskie $i$ sotsial'nye peremeny [Public Opinion Monitoring: Economic and Social Changes], 2018, 4, pp. 309-323. https://doi.org/10.14515/monitoring.2018.4.15. (In Russian)

Pustovoyt Yu. A. Protest kak krik, rabota i vera: formirovanie protestnoy identichnosti (po rezul'tatam issledovaniy v sibirskikh gorodakh) [Protest as a cry, work and faith: the formation of protest identity (based on the results of research in Siberian cities)]. Vestnik Tomskogo gosudarstvennogo universiteta. Filosofiya. Sotsiologiya. Politologiya [Vestnik of Tomsk State University. Philosophy. Sociology. Political Science], 2020, 57, pp. 277-284. doi: 10.17223/1998863X/57/26. (In Russian)

Radaev V. Millenialy. Kak menjaetsja rossijskoe obshhestvo [Millennials. How Russian society is changing]. Moscow: HSE, 2019, 230 p. (In Russian)

Sokolov M.M. Pokoleniya vmesto klassov? Vozrast i potrebitel'skaya revolyutsiya $\mathrm{v}$ Rossii [Generations instead of classes? Age and the consumer revolution in Russia]. Sotsiologiya vlasti [Sociology of Power], 2019, 31 (1), pp. 71-91. (In Russian)

Strauss A., Korbin Dzh. Osnovy kachestvennogo issledovanija: obosnovannaja teorija, procedury i tehniki [Fundamentals of qualitative research: grounded theory, procedures and techniques]. Moscow: Jeditorial URSS, 2001. 256 p. (In Russian)

Shtompka P. Vizualnaya sotsiologiya: fotografiya kak metod issledovaniya.[ Visual sociology: photography as a research method]. Moscow: Logos, 2007. 231 p. (In Russian)

Tvenge D. Pokolenie I. [ Generation I]. Moscow: Ripol Klassik, 2019. 454 p. (In Russian)

Tvenge D. Pokolenie selfi. Kto takie millenialy i kak nayti s nimi obshchiy yazyk. [The Selfie Generation. Who millennials are and how to find common ground with them]. Moscow: Litres, 2020. 336 p (In Russian)

Yanitskiy M. S. Sistema tsennostnykh orientatsiy "pokoleniya Z": sotsial'nye, kul'turnye i demograficheskie determinanty [The system of value orientations "generation Z": social, cultural and demographic determinants]. Sibirskii psikhologicheskiy zhurnal. [Siberian Psychological Journal], 2019, 72, pp. 46-67. (In Russian)

Yurchak A. Eto bylo navsegda, poka ne konchilos'. Poslednee sovetskoe pokolenie [It was forever until it was over. The last Soviet generation]. Moscow: New Literary Review, 2016. 664 p. (In Russian) 